RESIDENT

\& FELLOW

SECTION

Section Editor

Mitchell S.V. Elkind,

MD, MS

Rajesh Shankar Iyer, DM

Bejoy Thomas, MD

Address correspondence and reprint requests to Dr. Rajesh Shankar Iyer, Department of Neurology, Sree

Chitra Tirunal Institute for Medical

Sciences and Technology,

Trivandrum 695 011, Kerala, India

dr_rsh@hotmail.com

\title{
Teaching NeuroImages: \\ Reversal sign on CT in a child with hypoxic-ischemic brain injury
}

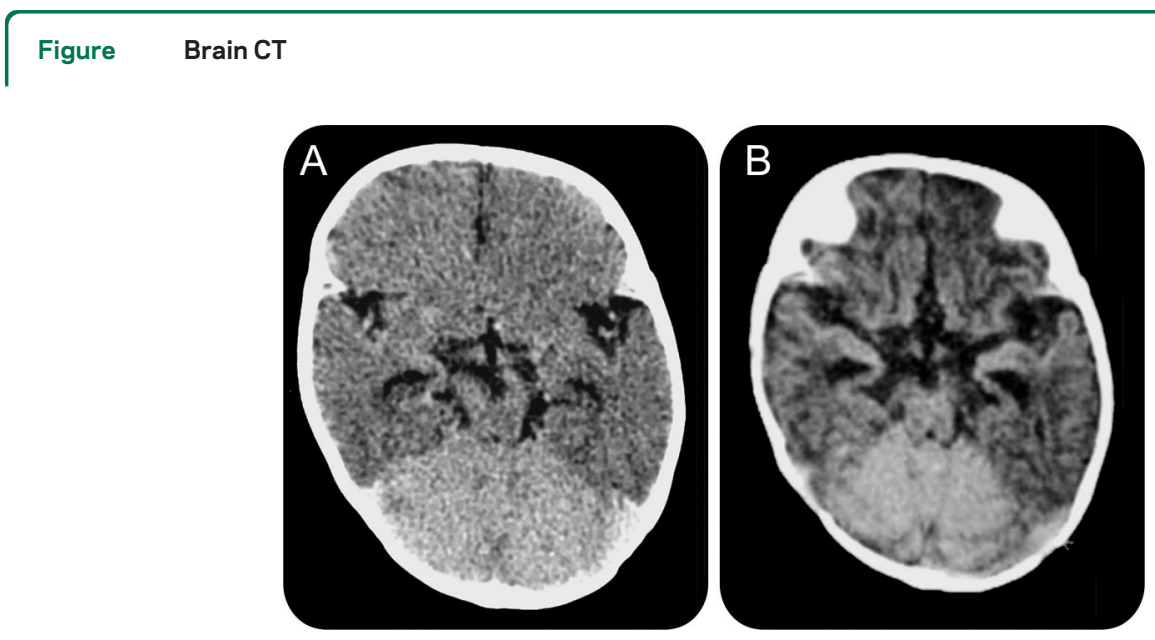

(A) Axial unenhanced CT study at the time of insult showing diffuse hypodensity of the cerebral parenchyma with normal cerebellar attenuation causing reversal sign. (B) Follow-up study 2 weeks later showing marked supratentorial volume reduction with persistent $\mathrm{CT}$ density difference.

A 7-month-old infant was admitted following cardiopulmonary arrest. She had complex congenital heart disease and severe respiratory infection and required ventilator support. On recovery, she had poor visual regard, bilateral spasticity, and developmental delay. Initial CT brain done on the third day of arrest (figure, A) and the follow-up scan done 2 weeks later (figure, B) showed the reversal sign. Reversal sign represents severe anoxic-ischemic brain injury resulting in irreversible brain damage and carries poor prognosis. ${ }^{1}$ Possible explanations for the high-density areas include preserved brain tissue, petechial hemorrhage, and mineralized neurons, whereas edema and tissue destruction could explain the low-density ones. ${ }^{1}$

\section{REFERENCE}

1. Han BK, Towbin RB, De Courten-Myers G, McLaurin RL, Ball WS Jr. Reversal sign on CT: effect of anoxic/ ischemic cerebral injury in children. AJR Am J Roentgenol $1990 ; 154: 361-368$. 


\title{
Neurology
}

\author{
Teaching NeuroImages: Reversal sign on $\mathrm{CT}$ in a child with hypoxic-ischemic brain \\ injury \\ Rajesh Shankar Iyer and Bejoy Thomas \\ Neurology 2011;76; 27 \\ DOI 10.1212/WNL.0b013e31820af92b
}

This information is current as of February 7, 2011

Updated Information \& Services

References

Subspecialty Collections

Permissions \& Licensing

Reprints including high resolution figures, can be found at: http://n.neurology.org/content/76/6/e27.full

This article cites 1 articles, 0 of which you can access for free at: http://n.neurology.org/content/76/6/e27.full\#ref-list-1

This article, along with others on similar topics, appears in the following collection(s):

Other cerebrovascular disease/ Stroke

http://n.neurology.org/cgi/collection/other_cerebrovascular_disease_st roke

Information about reproducing this article in parts (figures,tables) or in its entirety can be found online at:

http://www.neurology.org/about/about_the_journal\#permissions

Information about ordering reprints can be found online:

http://n.neurology.org/subscribers/advertise

Neurology ${ }^{\circledR}$ is the official journal of the American Academy of Neurology. Published continuously since 1951, it is now a weekly with 48 issues per year. Copyright Copyright (? 2011 by AAN Enterprises, Inc.. All rights reserved. Print ISSN: 0028-3878. Online ISSN: 1526-632X.

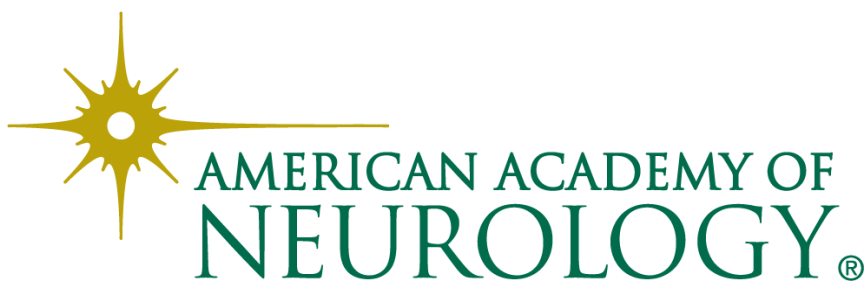

